\title{
Karakteristik Beton Mutu Tinggi dengan Substitusi Slag Baja dan Slag Nikel Sebagai Agregat Kasar
}

\author{
Komang Saka Suwindu ${ }^{\star 1}$ Herman Parung ${ }^{\star 2}$ Desi Sandy ${ }^{\star 3}$ \\ *1 Mahasiswa Program Studi Teknik Sipil, Universitas Kristen Indonesia Paulus, Makassar, Indonesia \\ windusakawindu@gmail.com \\ *2,3 Dosen Program Studi Teknik Sipil, Universitas Kristen Indonesia Paulus, Makassar, Indonesia
}

\begin{abstract}
ABSTRAK
Penelitian ini bertujuan untuk mengetahui nilai kuat tekan, tarik belah, dan kuat lentur pada beton mutu tinggi dengan variasi subtitusi slag baja dan slag nikel sebagai pengganti agregat kasar. Pengujian beton yang dilakukan adalah meliputi kuat tekan, tarik belah, dan kuat lentur. Proses penelitian dimulai dari pemeriksaaan karakteristik slag, dan agregat halus kemudian melakukan mix design dan membuat benda uji berupa silinder $150 \mathrm{~mm}$ x $300 \mathrm{~mm}$ sebanyak 36 buah dan balok $150 \mathrm{mmx} 150$ $\mathrm{mm} \times 600 \mathrm{~mm}$ sebanyak 9 buah. Hasil penelitian menunjukkan subtitusi slag baja dan slag nikel terhadap kuat tekan, kuat tarik belah, dan kuat lentur adalah semakin besar presentase slag nikel maka semakin besar kenaikan kuat tekan, kuat tarik belah dan kuat lentur. Nilai kuat tekan dengan subtitusi slag nikel 20\% meningkat 3,347\%; dan untuk subtitusi slag nikel $30 \%$ meningkat sebanyak 4,603\%. Nilai kuat tarik belah dengan subtitusi slag nikel $20 \%$ meningkat $30,137 \%$; dan untuk subtitusi slag nikel $30 \%$ meningkat sebanyak 46,585\%. Nilai kuat lentur dengan subtitusi slag nikel $20 \%$ meningkat $31,674 \%$; dan untuk subtitusi slag nikel $30 \%$ meningkat sebanyak $66,179 \%$. Hubungan kuat tekan dengan kuat tarik belah rata-rata yang diperoleh pada beton mutu tinggi dengan subtitusi slag nikel 0\%, 20\%, 30\% pada umur 28 hari adalah 9,3\%. Hubungan kuat tekan dengan kuat lentur ratarata diperoleh pada beton mutu tinggi dengan subtitusi slag nikel $0 \%, 20 \%, 30 \%$ pada umur 28 hari adalah $0,621 \sqrt{f^{\prime} c}$.
\end{abstract}

Kata Kunci : slag baja, slag nikel, kuat tekan, kuat tarik belah, kuat lentur

\begin{abstract}
This study aims to determine the value of compressive strength, split tensile, and flexural strength in high quality concrete with variations in the substitution of steel slag and nickel slag as a substitute for coarse aggregate. Concrete tests performed include compressive strength, split tensile strength, and flexural strength. The research process starts from checking the characteristics of slag, and fine aggregate then mix designs and make test specimens in the form of cylinders of $150 \mathrm{~mm} \times 300 \mathrm{~mm}$ as many as 36 pieces and beams of $150 \mathrm{~mm} \times 150 \mathrm{~mm} \times 600 \mathrm{~mm}$ as many as 9 pieces. The results showed the substitution of steel slag and nickel slag on compressive strength, split tensile strength, and flexural strength, the greater the percentage of nickel slag, the greater the increase in compressive strength, split tensile strength and flexural strength. Compressive strength value with $20 \%$ nickel slag substitution increased 3.347\%; and for 30\% nickel slag substitution increased by $4.603 \%$. The value of split tensile strength with $20 \%$ nickel slag substitution increased by $30.137 \%$; and for $30 \%$ nickel slag substitution increased by $46.585 \%$. The value of flexural strength with substitution of $20 \%$ nickel slag increased $31.674 \%$; and for $30 \%$ nickel slag substitution increased by $66.179 \%$. The relationship between compressive strength and average tensile strength obtained in high quality concrete with nickel slag substitution $0 \%, 20 \%, 30 \%$ at 28 days is $9.3 \%$. The relationship of compressive strength with the average flexural strength obtained in high quality concrete with nickel slag substitution of $0 \%, 20 \%, 30 \%$ at 28 days is $0.621 \sqrt{f^{\prime} c}$.
\end{abstract}

Keywords: steel slag, nickel slag, compressive strength, split tensile strength, flexural strength 


\section{PENDAHULUAN}

Salah satu bidang industri yang saat ini makin maju perkembangannya adalah industri peleburan baja dan industri pengolahan nikel. Seiring meningkatnya pertumbuhan industri maka makin meningkat pula limbah yang dihasilkan oleh industri tersebut. Dalam perkembangannya, limbah slag yang dihasilkan oleh industri peleburan baja ini (PT. Barawaja, Makassar) semakin menumpuk hingga mencapai rata-rata 14 ton per bulan dan limbah slag yang dihasilkan oleh industri pengolahan nikel ini (PT. Vale Indonesia, Sorowako) mencapai 4,6 juta ton pada tahun 2018. Sehingga perlu dilakukan penanganan yang serius agar tidak mencemari lingkungan. Salah satu limbah yang dihasilkan dari industri tersebut adalah limbah padat atau slag. Secara struktur fisik slag lebih kaku, padat, dan keras dibandingkan dengan agregat kasar alami. Berdasarkan sifat fisik slag tersebut, penulis ingin meneliti kekuatan beton dengan menggunakan slag baja sebagai pengganti agregat kasar, dan slag nikel sebagai bahan subtitusi.

Tujuan penelitian ini adalah untuk mengetahui nilai kuat tekan, kuat tarik belah, dan kuat lentur pada beton mutu tinggi dengan variasi substitusi slag baja dan slag nikel pada campuran beton sebagai substitusi agregat kasar dan mengetahui hubungan kuat tekan $\left(\mathrm{f}_{\mathrm{c}} \mathrm{c}\right)$ dengan kuat tarik belah $\left(\mathrm{f}_{\mathrm{t}}\right)$ dan hubungan kuat tekan $\left(f_{c}^{\prime}\right)$ dengan kuat lentur $\left(f_{r}\right)$ dari beton yang disubtitusi slag baja dan slag nikel sebagai agregat kasar.

\section{Beton Mutu Tinggi}

Beton mutu tinggi adalah beton yang memiliki kuat tekan diatas beton normal. Meskipun teknologi beton telah terbukti kemampuannya, oleh karena tuntutan konstruksi terhadap kekuatan dan keawetan, teknologi ini dapat ditingkatkan efektivitas kinerjanya dengan memperbaiki mutu beton yang dikenal dengan sebutan beton mutu tinggi. Banyak yang mendefinisikan tentang kategori beton mutu tinggi disesuaikan dengan kuat tekannya, seperti:

a. CSA (Concrete Strength Admixture) mendefinisikan beton mutu tinggi untuk beton dengan kuat tekan f'c lebih besar dari $50 \mathrm{MPa}$.

b. Menurut PD T-04-2004-C tentang Tata Cara Pembuatan dan Pelaksanaan Beton

Berkekuatan Tinggi, yang tergolong beton bermutu tinggi adalah beton yang memiliki kuat tekan antara 40 - $80 \mathrm{MPa}$.

c. Beton mutu tinggi (high strength concrete) yang tercantum dalam SNI 03-6468-2000 didefinisikan sebagai beton yang mempunyai kuat tekan yang disyaratkan lebih besar sama dengan 41,4 MPa.

\section{Faktor Air Semen (FAS)}

Untuk menghasilkan sebuah beton yang bermutu tinggi FAS dalam beton haruslah rendah, namun hal ini menyebabkan kesulitan dalam pengerjaan. Umumnya nilai FAS minimum untuk beton normal sekitar 0,4 dan nilai maksimal 0,65. Tujuan pengurangan FAS ini adalah untuk mengurangi hingga seminimal mungkin porositas beton yang dibuat sehingga akan dihasilkan beton mutu tinggi. Pada beton mutu tinggi atau sangat tinggi, Supartono (1998) FAS dapat diartikan sebagai meter to comentious ratio, yaitu berat air terhadap berat total semen dan aditif comentious yang umumnya di tambahkan pada campuran beton mutu tinggi.

\section{Material Penyusun Beton Mutu Tinggi}

Secara umum bahan yang digunakan dalam pembuatan beton mutu tinggi adalah agragat halus, agregat kasar, PCC (Portland Cemen Composite), air, dan bahan tambah.

\section{a. Agregat halus}

Agregat halus dapat berupa pasir alam, pasir hasil olahan atau gabungan dari kedua pasir tersebut. Bentuk agregat halus akan mempengaruhi kualitas mutu beton yang akan dibuat. Menurut Mulyono (2004), agregat berbentuk bulat mempunyai rongga udara minimum $33 \%$ lebih kecil dari rongga udara yang dipunyai oleh bentuk lainnya. Agregat halus yang digunakan untuk campuran harus terdiri dari butir-butir yang tajam dan keras, bersifat kekal yang tidak mudah hancur atau pecah oleh pengaruh cuaca, seperti terik matahari dan hujan. Kadar lumpur yang terkandung dalam agregat halus tidak boleh lebih dari $6 \%$, bila kadar lumpur melampaui $6 \%$ maka agregat harus dicuci. Berat jenis dan penyerapan agregat, dan semakin tinggi nilai berat jenis maka semakin kecil pula penyerapannya. Menurut SNI 03-2847-2002, agregat halus merupakan agregat yang mempunyai ukuran butir maksimum sebesar $5,00 \mathrm{~mm}$.

\section{b. Agregat kasar}

Agregat kasar dapat berupa kerikil, pecahan kerikil, batu pecah, terak tanur tiup atau beton semen hidrolis yang dipecah. Sesuai dengan SNI 03-28472002 , bahwa agregat kasar merupakan agregat yang mempunyai ukuran butir antara $5,00 \mathrm{~mm}$ sampai 20 $\mathrm{mm}$.

\section{c. Portland Cemen Composite (PCC)}

Menurut SNI 15-7064-2004, defenisi Portland Cemen Composite adalah bahan pengikat hidrolis penggilingan bersama-sama terak semen Portland dan gyps dengan satu atau bahan organik lain. Anorganik tersebut antara lain terak tanur tinggi (blast furnace slag), pozzolan, senyawa silica, batu kapur dengan total anorganik $6 \%-35 \%$ dari massa semen portland composite. 


\section{d. Air}

Air merupakan salah satu bahan yang diperlukan dalam pembuatan beton yang sebagai bahan pencampur dan pengaduk antara semen dan agregat.

\section{e. Bahan tambah Silica Fume}

Bahan tambah silica fume merupakan generasi terbaru additive yang sangat efektif untuk menghasilkan beton dengan kualitas tinggi sesuai dengan standar ASTM 1240 (2000).

\section{Karakteristik Beton}

a. Kuat tekan beton

Kuat tekan beton adalah besarnya beban per satuan luas, yang menyebabkan benda uji beton hancur dibebani dengan gaya tekan tertentu yang dihasilkan oleh mesin tekan.

Untuk perhitungan kuat tekan beton dapat menggunakan persamaan berikut :

$$
f^{\prime} c=P
$$

A

Keterangan :

$$
\begin{aligned}
& f^{\prime} C=\text { kuat tekan beton }(\mathrm{MPa}) \\
& P=\text { beban maksimum }(\mathrm{N}) \\
& A=\text { luas penampang benda uji }\left(\mathrm{mm}^{2}\right)
\end{aligned}
$$

Mekanisme pengujian kuat tekan beton ditunjukkan pada Gambar 1.

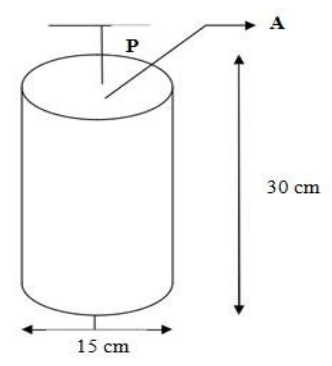

Gambar 1. Uji kuat tekan

b. Kuat tarik belah beton

Kuat tarik belah adalah kuat tarik beton yang ditentukan berdasarkan kuat tarik belah dari silinder beton yang ditekan pada sisi panjangnya. Kekuatan tarik belah beton relatif rendah, nilai kuat tekan dan tarik belah beton tidak berbanding lurus. Setiap usaha perbaikan untuk kekuatan tekan hanya disertai dengan peningkatan kecil nilai kuat tariknya. Kekuatan tarik lebih sulit diukur dibandingkan dengan kekuatan tekan karena masalah penjepit pada mesin.
Tegangan tarik yang timbul sewaktu benda uji tarik belah disebut split cylinder strength atau kuat tarik belah.

c. Kuat lentur beton

Kuat lentur beton adalah kemampuan balok beton untuk menahan gaya dengan arah tegak lurus sumbu yang diberikan padanya sampai balok beton patah dan dinyatakan dalam Mega Pascal (MPa). Kuat lentur beton dengan mekanisme pengujian yang ditunjukkan pada Gambar 3.
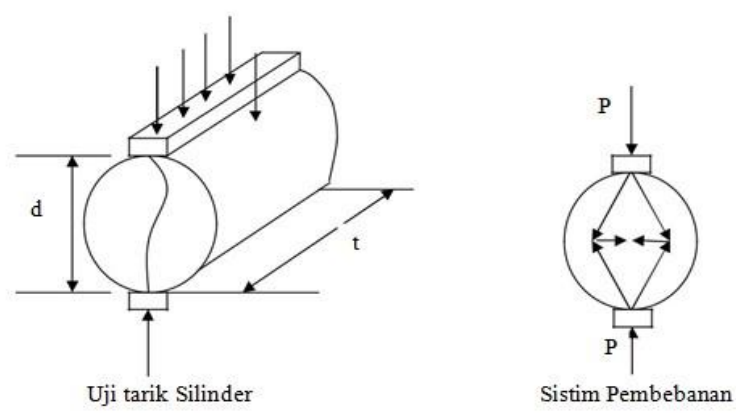

Gambar 2. Uji tarik belah

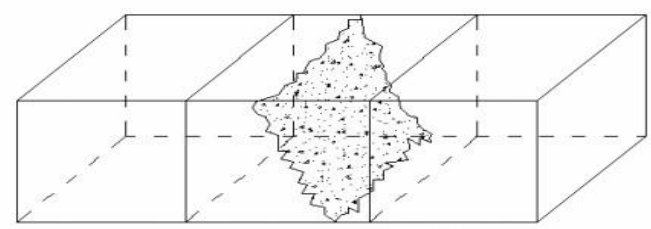

Gambar 3. Mekanisme pengujian kuat lentur dengan keruntuhan di tengah bentang

\section{Limbah Padat (slag) Baja}

Pada peleburan baja, biji besi atau besi bekas dicairkan dengan kombinasi batu gamping, delomite atau kapur, pembuatan baja dimulai dari menghilangkan ion-ion pengotor baja, diantaranya aluminium, silicon dan phosphor. Untuk menghilangkan ion-ion pengotor tersebut diperlukan kalsium yang terdapat pada batu kapur. Campuran kalsium, alumonium, silicon dan phosphor membentuk (slag) yang bereaksi pada temperatur $1600^{\circ} \mathrm{C}$ dan membentuk cairan, bila cairan ini didinginkan maka akan terjadi kristal, dapat digunakan sebagai campuran semen dan dapat juga sebagai pengganti agregat.

\section{Limbah padat (slag) nikel}


Limbah nikel merupakan sejenis batuan hasil pembuangan dari pembakaran feronikel, berwarna kelabu perak dan memiliki sifat-sifat menyerupai batu dan unsur silikat serta kapur yang tterkandung di dalamnya cukup tinggi. Slag nikel mempunyai kandungan Kalsium Oksida $(\mathrm{CaO})$ dan Silicon dioksida $\left(\mathrm{SiO}_{2}\right)$ yang tinggi yaitu $42,30 \%$ dan $26,56 \%$ yang perlu diperhatikan dari sifat kimia slag dalam hubungannya dengan campuran beton adalah kandungan $\mathrm{CaO}$ dan $\mathrm{SiO}_{2}$. Dalam hal ini $\mathrm{CaO}$ bebas dalam campuran beton akan bereaksi dengan air selama proses hidrasi menjadi $\mathrm{Ca}(\mathrm{OH})_{2}$, reaksi ini yang akan menyebabkan beton mengembangan.

Beberapa penelitian sejenis yaitu Adiwijaya et.al menggunakan slag baja sebagai pengganti agregat untuk mengetahui karakteristik self compacting concrete. Hasil penelitian berdasarkan persyaratan beton SCC, dapat digunakan sebagai agregat kasar dan agregat halus [1].

Dionisius et.al menggunakan beton agregat ringan dengan substitusi parsial batu apung sebagai agregat kasar. Hasil penelitian diperoleh nilai densitiy $1850 \mathrm{~kg} / \mathrm{m} 3$, pada substitusi parsial batu apung $20 \%$ dari berat agregat kasar diperoleh kuat tekan dan kuat Tarik belah beton maksimum yaitu 39.21 Mp dan 4.05 Mpa [2].

Nora et.al menguji kuat tekan beton mutu tinggi hybrid dengan substitusi semen dan agregat halus serta penambahan nano material bijih besi . Hasil kuat tekan maksimum pada beton umur 7 hari adalah $44.28 \mathrm{Mpa}, 28$ hari adalah $59.48 \mathrm{Mpa}$, dan umur 56 hari $69.71 \mathrm{Mpa}$ [3].

Ervianto et.al menggunakan bahan tambah fly ash dan zat adiktif untuk menguji kuat tekan beton mutu tinggi. Hasil penelitian nilai kuat tekan menjadi semakin tinggi seiring bertambahnya fly ash, tetapi nilai kuat tekan menjadi turun apabila penggunaan fly ash dalam jumlah yang banyak ditujukan sebagai pengganti sebagian semen [4].

Yusra et.al menggunakan bahan tambah fly ash batu bara untuk mengetahui kuat tekan beton mutu tinggi. Hasil penelitian untuk umur 28 hari dalam pengujian kuat tekan dengan nilai 56.21 Mpa (fly ash $0 \%$ dan 5\%), 51.68\% (8\%), $56.59 \mathrm{Mpa}(10 \%)$, dan $60.36 \mathrm{Mpa}$ (15\%), Untuk umur pengujian 56 hari, $0 \%$ menghasilkan kuat tekan $(64,13 \mathrm{MPa}), 5 \%$ $(63,26 \mathrm{MPa}), 8 \%(56,59 \mathrm{MPa}), 10 \%(63,94 \mathrm{MPa})$, dan $15 \%(66,96 \mathrm{MPa})[5]$.

Ardhyan et.al menganalisis pengaruh penggunaan limbah hasil pembakaran cangkang sawit dan pasir pozzolan alami sebagai pengganti agregat serta penggunaan abu pasir pozzolan sebagai aditif pengganti semen. Hasil penelitian bongkahan cangkang sawit dan pasir pozzolan sebagai substitusi serta pemakaian abu pozzolan sebagai aditif dapat meningkatkan nilai kuat tekan[6].

\section{METODOLOGI PENELITIAN}

\section{Lokasi Pengambilan Material}

Material yang digunakan adalah agregat halus dari Bili-bili, Kabupaten Gowa, Sulawesi Selatan. Slag Baja dari PT. Barawaja, Makassar dan Slag Nikel berasal dari Sorowako, Kabupaten Luwu Timur, Sulawesi Selatan sebagai pengganti agregat kasar.

\section{HASIL DAN PEMBAHASAN}

\section{A. Hasil Pemeriksaan Karakteristik Material}

\section{Agregat Halus}

Hasil pengujian karakteristik agregat halus semua memenuhi berdasarkan interval SNI. Kadar air $3,307 \%$, kadar organik no.1, kadar lumpur 3,0\%, SSD 2,591, penyerapan 1,730 , berat volume padat $1626,250 \mathrm{~kg} / \mathrm{m}^{3}$, berat volume gembur 1585,485 $\mathrm{kg} / \mathrm{m}^{3}$, dan modulus kehalusan 2,600. Hasil pengujian agregat halus dapat dilihat pada Tabel 1. 
Tabel 1. Hasil pengujian karakteristik agregat halus

\begin{tabular}{|c|c|c|c|c|}
\hline No & Karakteristik & Hasil & Interval SNI & Keterangan \\
\hline 1. & Kadar Air, \% & 3,307 & $3,00-5,00$ & Memenubi \\
\hline 2. & Kadar Qrganik & No.1 & $<$ No.3 & Memenubi \\
\hline 3. & Kadar Lumpur, \% & 3,0 & $0,20-6,00$ & Memenuhi \\
\hline 4. & Berat Jenis SSD, \% & 2,591 & $1,60-3,20$ & Memenubi \\
\hline 5. & Absorpsi (Penverapan)\% & 1,730 & $0,20-2,00$ & Memenubi \\
\hline 6. & Berat Volume Padat, $\mathrm{kg} / \mathrm{m}^{3}$ & 1626,2 & $1400-1900$ & Memenubi \\
\hline 7. & Berat Volume Gembur, $\mathrm{kg} / \mathrm{m}^{3}$ & 85 & $1400-1900$ & Memenubi \\
\hline 8. & Modulus Kehalusan & 2,600 & $2,20-3,10$ & Memenubi \\
\hline
\end{tabular}

\section{Agregat Kasar}

Hasil pengujian agregat kasar slag baja dan slag nikel

Hasil pengujian karakteristik agregat kasar slag baja

untuk semua karakteristik memenuhi standar SNI.

masing-masing dapat dilihat pada Tabel 2 dan 3.

Tabel 2. Hasil pengujian karakteristik slag baja

\begin{tabular}{|c|c|c|c|c|}
\hline No & Karakteristik & Hasil & Interval SNI & Keterangan \\
\hline 1. & Kadar Jumpur, \% & 0,847 & $0,2-1$ & Memenubi \\
\hline 2. & Kadar air, \% & 0,685 & $0,5-2,0$ & Memenubi \\
\hline 3. & Berat volume padat, kg/ltr & 1,790 & $1400-1900$ & Memenubi \\
\hline 4. & Berat volume gembur, $\mathrm{kg} / \mathrm{ltr}$ & 1.572 & $1400-1900$ & Memenubi \\
\hline 5. & Penverapan \% & 1.318 & $0.2-2.0$ & Memenubi \\
\hline 6. & SSD & 3.141 & $1.6-3.2$ & Memenubi \\
\hline
\end{tabular}

Tabel 3. Hasil pengujian agregat kasar (Slag nikel) 


\begin{tabular}{lllll}
\hline No & Karakteristik & Hasil & Interval SNI & Keterangan \\
\hline 1. & Kadar lumpur, \% & 0,40 & $0,2-1$ & Memenubi \\
\hline 2. & Kadar air, \% & 1,359 & $0,5-2,0$ & Memenubi \\
\hline 3. & Berat volume padat, kg//tr & 1.485 & $1400-1900$ & Memenubi \\
\hline 4. & Berat volume gembur, kg/ltr & 1,427 & $1400-1900$ & Memenubi \\
\hline 5. & Renverapan \% & 1,441 & $0,20-2,00$ & Memenubi \\
\hline 6. & Berat ienis (SSD) & 2,687 & $1,6-3,2$ & Memenubi \\
\hline
\end{tabular}

\section{B. Hasil Komposisi Mix Design}

Komposisi kebutuhan bahan campuran beton untuk substitusi slag nikel $0 \%$ dimana slag baja 965,243, untuk slag nikel 20\% slag baja 193,049, dan slag nikel $30 \%$ slag baja 289,573 . Komposisi kebutuhan bahan campuran beton dapat dilihat pada Tabel 4 .

Tabel 4. Komposisi kebutuhan bahan campuran beton untuk $1 \mathrm{~m}^{3}$

\begin{tabular}{cccccccc}
\hline & & \multicolumn{6}{c}{ Berat $(\mathrm{kg})$} \\
\cline { 3 - 8 } No & $\begin{array}{c}\text { Subtitusi } \\
\text { Slag } \\
\text { Nikel }\end{array}$ & Semen & Air & $\begin{array}{c}\text { Agregat } \\
\text { Halus }\end{array}$ & $\begin{array}{c}\text { Slag } \\
\text { Baja }\end{array}$ & Slag Nikel & $\begin{array}{c}\text { Silica } \\
\text { Fume }\end{array}$ \\
\hline 1 & $0 \%$ & 482,5 & 193 & 860,212 & 965,243 & 0 & 19,3 \\
\hline 2 & $20 \%$ & 482,5 & 193 & 860,212 & 772,194 & 193,049 & 19,3 \\
\hline 3 & $30 \%$ & 482,5 & 193 & 860,212 & 675,670 & 289,573 & 19,3 \\
\hline
\end{tabular}

\section{Hasil Pemeriksaan Kuat Tekan Beton}

Berikut merupakan hasil perhitungan dari kuat tekan beton dari variasi subtitusi slag nikel $0 \%, 15 \%$, dan $30 \%$. Kuat tekan beton actual rata-rata untuk 7,21 , dan 28 hari masing-masing variasi substitusi slag adalah 24,899 $\mathrm{MPa}$, 38,292 $\mathrm{MPa} 45,082 \mathrm{MPa}$, 26,408 MPa, 42,064 MPa, 46,592 MPa, 27,162 MPa, $43,196 \mathrm{MPa}$, dan 47,346 MPa. Kuat tekan beton aktual rata-rata dari variasi substitusi slag nikel dapat di lihat pada Tabel 5,6, dan 7.

Tabel 4. Kuat tekan beton dari variasi substitusi slag

\begin{tabular}{|c|c|c|c|c|}
\hline \multirow[b]{2}{*}{ Subtitusi Slag } & & \multicolumn{2}{|c|}{ nikel 0\% } & \multirow[b]{2}{*}{$\begin{array}{l}\text { Kuat Tekan } \\
\text { Beton Aktual } \\
\text { Rata-rata (Mpa) }\end{array}$} \\
\hline & $\begin{array}{l}\text { Umur } \\
\text { (Hari) }\end{array}$ & $\begin{array}{l}\text { Beban } \\
\text { Maksimum (KN) }\end{array}$ & $\begin{array}{l}\text { Kuat Tekan Beton } \\
\text { Aktual Rata rata } \\
\text { (Mpa) }\end{array}$ & \\
\hline \multirow{9}{*}{$\begin{array}{l}\text { Baja } 100 \% \text { dan } \\
\text { Nikel } 0 \%\end{array}$} & 7 & 490 & 27.728 & \multirow[t]{3}{*}{24.899} \\
\hline & & 430 & 24.333 & \\
\hline & & 400 & 22.635 & \\
\hline & \multirow[t]{3}{*}{21} & 660 & 22.635 & \multirow[t]{3}{*}{38.292} \\
\hline & & 670 & 37.348 & \\
\hline & & 700 & 37.914 & \\
\hline & \multirow[t]{3}{*}{28} & 790 & 44.705 & \multirow[t]{3}{*}{45.082} \\
\hline & & 820 & 46.403 & \\
\hline & & 780 & 44.139 & \\
\hline
\end{tabular}

Tabel 5. Kuat tekan beton dari variasi substitusi slag nikel $15 \%$

\begin{tabular}{lllll}
\hline Subtitusi_Slag & $\begin{array}{l}\text { Umur. } \\
\text { (Hari) }\end{array}$ & $\begin{array}{l}\text { Beban } \\
\text { Maksimum (KN) }\end{array}$ & $\begin{array}{l}\text { Kuat Tekan Beton } \\
\text { Aktual Rata rata } \\
\text { (Mpa) }\end{array}$ & $\begin{array}{l}\text { Kuat Tekana } \\
\text { Beton Aktual } \\
\text { Rata-rata (Mpa) }\end{array}$ \\
\hline Baja 85\% dan & 7 & 460 & 26.031 & 26.408 \\
Nikel 15\% & & 420 & 23.767 & \\
& 21 & 520 & 29.426 & \\
& & 700 & 39.612 & 42.064 \\
& & 750 & 44.139 & \\
\cline { 2 - 5 } & 28 & 800 & 42.441 & \\
& & 850 & 45.271 & 46.591 \\
& 820 & 48.100 & \\
\hline
\end{tabular}

Tabel 6. Kuat tekan beton dari variasi substitusi slag nikel $30 \%$

\begin{tabular}{lllll}
\hline Subtitusi_Slag & $\begin{array}{l}\text { Umur } \\
\text { (Hari) }\end{array}$ & $\begin{array}{l}\text { Beban } \\
\text { Maksimum (KN) }\end{array}$ & $\begin{array}{l}\text { Kuat Tekan Beton } \\
\text { Aktual Rata rata } \\
\text { (Mpa) }\end{array}$ & $\begin{array}{l}\text { Kuat Jekan } \\
\text { Beton Aktual } \\
\text { Rata-rata (Mpa) }\end{array}$ \\
\hline Baja 70\% dan & 7 & 480 & 27.162 & 27.162 \\
Nikel 30\% & & 470 & 26.597 & \\
& 21 & 490 & 27.728 & \\
& & 760 & 43.007 & 43.196 \\
& 750 & 42.441 & \\
\cline { 2 - 5 } & 28 & 880 & 44.139 & \\
& & 840 & 47.534 & 47.346 \\
& & 850 & 46.403 & \\
\hline
\end{tabular}

\section{Hasil Pemeriksaan Kuat Tarik Belah Beton}

Uji kuat tarik belah beton bertujuan untuk mengetahui berapa gaya tarik maksimal yang diberikan kepada beton dalam satuan KN. Setelah mencapai umur rencana perawatan benda uji 28 hari, maka setiap benda uji dibagi berdasarkan variasi subtitusi slag baja yang digunakan, kemudian dilakukan uji tarik belah di laboratorium. Berikut hasil pengujian kuat tarik belah beton. 


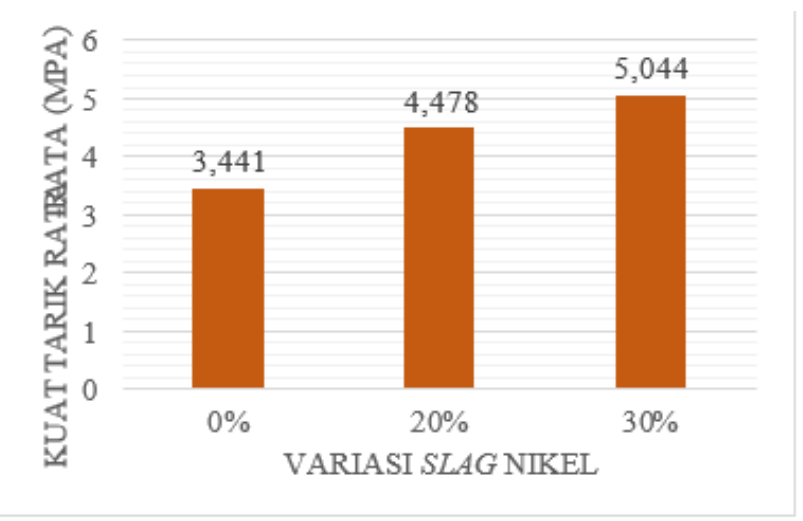

Gambar 3. Diagram Batang Hubungan Variasi Slag dan Kuat Tarik Belah

\section{E. Hasil Pemeriksaan Kuat Lentur}

Kemampuan balok beton yang diletakkan pada dua perletakan untuk menahan gaya dengan arah tegak lurus sumbu benda uji, yang diberikan kepadanya, sampai benda uji patah, dinyatakan dalam Mega
Pascal (Mpa) gaya per satuan luas. Setelah mencapai umur rencana perawatan benda uji 28 hari, maka setiap benda uji dibagi berdasrkan variasi faktor air semen yang digunakan, kemudian dilakukan uji kuat lentur di laboratorium. Berikut ini adalah hasil pengujian kuat lentur beton.

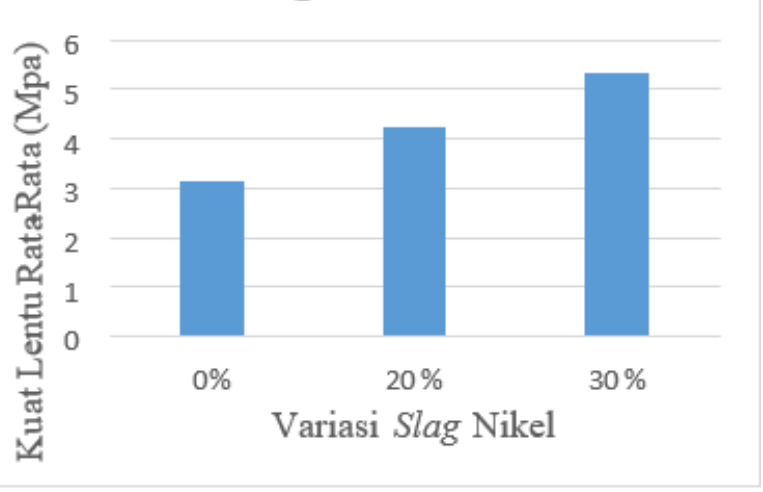

Gambar 4. Diagram Batang Hubungan Variasi Slag dan Kuat Lentur Beton

Tabel 7. Kuat lentur beton dari variasi substitusi slag nikel

\begin{tabular}{lllll}
\hline $\begin{array}{l}\text { Variasi } \\
\text { Slag Nikel } \\
\text { (\%) }\end{array}$ & $\begin{array}{l}\text { Beban } \\
\text { Maksimum } \\
\text { Aktual (Ton) }\end{array}$ & $\begin{array}{l}\text { Beban } \\
\text { Maksimum (kN) }\end{array}$ & $\begin{array}{l}\text { Kuat lentur } \\
\text { beton (MPa) }\end{array}$ & $\begin{array}{l}\text { Kuat lentur } \\
\text { beton rata- } \\
\text { rata (MPa) }\end{array}$ \\
\hline $\mathbf{0}$ & 2.2 & 21.582 & 3.325 & 3.124 \\
& 2.4 & 23.544 & 3.628 & \\
\hline $\mathbf{2 0}$ & 1.6 & 15.696 & 2.418 & \\
& 2.4 & 23.544 & 3.628 & \\
& 2.8 & 27.462 & 4.232 & \\
\hline $\mathbf{3 0}$ & 3.2 & 31.392 & 4.837 & 5.341 \\
& 3.6 & 35.316 & 5.441 & \\
\hline
\end{tabular}

\section{Pembahasan}

Kadar lumpur 0,847\%, kadar air 0,685\%, berat volume padat $1,790 \mathrm{~kg} / \mathrm{ltr}$, berat volume gembur $1,572 \mathrm{~kg} / \mathrm{ltr}$, penyerapan $2 \%$. Untuk hasil pengujian agregat kasar-slag nikel kadar lumpur 0,40\%, kadar air $1,359 \%$, berat volume padat $1485 \mathrm{~kg} / \mathrm{ltr}$, berat volume gembur $1,427 \mathrm{~kg} / \mathrm{ltr}$, penyerapan $1,441 \%$, SSD 2,687.

Nilai kuat tekan, kuat tarik belah, dan kuat lentur yang diperoleh pada beton dengan subtitusi slag nikel 0\%, 20\%, 30\% umur 28 hari meningkat.

Hubungan kuat tekan dengan kuat tarik belah ratarata yang diperoleh pada beton mutu tinggi dengan substitusi slag nikel $0 \%, 20 \%, 30 \%$ pada umur 28 hari adalah $9,3 \%$.

\section{KESIMPULAN}

Nilai kuat tekan, kuat tarik belah, dan kuat lentur yang diperoleh pada beton dengan subtitusi slag nikel 0\%, 20\%, 30\% umur 28 hari meningkat. Nilai kuat tekan dengan subtitusi slag nikel 20\% meningkat 3,347\%; dan untuk subtitusi slag nikel $30 \%$ meningkat sebanyak $4,603 \%$. Nilai kuat tarik belah dengan subtitusi slag nikel $20 \%$ meningkat $30,137 \%$; dan untuk subtitusi slag nikel 30\% meningkat sebanyak $46,585 \%$. Nilai kuat lentur dengan subtitusi slag nikel $20 \%$ meningkat $31,674 \%$; dan untuk subtitusi slag nikel $30 \%$ meningkat sebanyak $66,179 \%$.

Hubungan kuat tekan dengan kuat tarik belah ratarata yang diperoleh pada beton mutu tinggi dengan substitusi slag nikel 0\%, 20\%, 30\% pada umur 28 hari adalah 9,3\%.

Hubungan kuat tekan dengan kuat lentur rata-rata yang diperoleh pada beton mutu tinggi dengan substitusi slag nikel $0 \%, 20 \%, 30 \%$ pada umur 28 hari adalah $0,621 \sqrt{f^{\prime} c}$. 


\section{DAFTAR PUSTAKA}

[1] Adiwijaya dan I. T. Datu, 2018, "Penerapan Slag Baja Sebagai Pengganti Agregat Pada Karakteristik Self Compacting Concrete," in Prosiding Seminar Nasional Hasil Penelitian dan Pengabdian Masyarakat p. 166-171.

[2] D. T. Ab and I. G. P. Raka, 2010, "Beton Agregat Ringan dengan Substitusi Parsial Batu Apung Sebagai Agregat Kasar," in Prosiding Konferensi Nasional Teknik Sipil 4. p. 173 180.

[3] N. Usriana, 2018, "Kuat Tekan Beton Mutu Tinggi Hybrid dengan Substitusi Semen dan Agregat Halus Serta Penambahan Nano Material Buih Besi." J. Arsip Rekayasa Sipil dan Perencanaan vol. 1, no.1, p, $179-188$.
[4] Moh. Ervianto, F. Saleh, and H. Prayuda, 2016, "Kuat Tekan Beton Mutu Tinggi Menggunakan Bahan Tambah Abut Terbang dan Zat Adiktif," SINERGI, vol. 20, no. 3, p. 199.

[5] A. Yusra, T. B. Aulia, and J. Jufriadi, 2018, "Pengaruh Bahan Tambah Fly Ash Batu Bara Terhadap Kuat Tekan Beton Mutu Tinggi," J. Tek. Sipil Dan Teknol. Konstr., vol. 1, no. 1, 2, doi: 10.35308/jts-utu.v1i1.717.

[6] M.Z. Ardian, 2016, "Pengaruh Substitusi Parsial Agregat dan Aditif Terhadap Sifat Mekanis Beton Mutu Tinggi." J. Teknik Sipil Universitas Syiah Kuala . 2016. 